\title{
Kajian Potensi Kerusakan Lingkungan Fisik Akibat Penambangan Breksi Batu Apung, Di Desa Segoroyoso, Kec. Pleret, Kab. Bantul, Provinsi DIY
}

\author{
Agus Candra ${ }^{1}$ \\ ${ }^{1}$ Dosen Program Studi Teknik Sipil, Universitas Islam Kuantan Singingi \\ Jalan Gatot Subroto KM. 7, Teluk Kuantan Singingi, Riau, 29566
}

\begin{abstract}
Abstrak
Sumber daya alam merupakan salah satu modal dasar dalam pembangunan nasional. Oleh karena itu harus dimanfaatkan sebesar-besarnya untuk kepentingan rakyat dengan memperhatikan kelestarian lingkungan hidup sekitarnya. Sumber daya alam di Indonesia cukup banyak dan melimpah sehingga terkadang sebagian dieksploitasi secara besar-besaran untuk kebutuhan pembangunan. Penambangan breksi batuapung di Desa Segoroyoso, Kecamatan Pleret Kabupaten Bantul dilakukan secara tradisional. Penambangan dilakukan tanpa memperhatikan keselamatan dan kelestarian fungsi lingkungan sangat mengkhawatirkan disamping kondisi lahan yang semakin kritis dan berdampak terhadap kerusakan lahan disekitar penambangan. Kerusakan yang dapat ditimbulkan akibat dari kegiatan penambangan breksi batuapung adalah dapat merusak komponenkomponen lingkungan fisik yang ada, seperti tanah, batuan, vegetasi yang ada pada kawasan tersebut dan menimbulkan kerusakan terhadap kelestarian fungsi lingkungan.
\end{abstract}

Metode yang digunakan dalam penelitian ini adalah metode survey, pemetaan, dan analisis dengan menggunakan pengharkatan (scoring) yang mengacu pada Kep. Gub. Prop. DIY No. 63 Tahun 2003. Parameter yang digunakan untuk menentukan tingkat kerusakan lingkungan fisik penambangan breksi batuapung adalah Batas kedalaman lubang galian, Penyelamatan tanah pucuk, Relief dasar galian, Batas kemiringan tebing galian, tinggi dinding galian, upaya reklamasi, kondisi jalan, aksesibilitas. Tingkat kerusakan lingkungan fisik akibat penambangan breksi batuapung diperoleh dari hasil penjumlahan skor setiap parameter. Kriteria kerusakan dibagi menjadi 3 tingkat, yaitu: Tingkat I dengan kriteria rusak ringan, Tingkat II dengan kriteria rusak sedang, dan Tingkat III dengan kriteria rusak berat.

Berdasarkan hasil scoring dari parameter yang tercantum di atas, penelitian ini menunjukan bahwa yang sangat mempengaruhi potensi kerusakan lahan akibat penambangan breksi batuapung di Desa Segoroyoso, Kec. Pleret, Kab. Bantul adalah tinggi dinding galian, kemiringan dinding galian, upaya reklamasi dan relief dasar galian, hampir disetiap lokasi penelitian (blok-1, blok-2, blok-3) mempunyai harkat 2 dan 3 dengan kriteria rusak ringan dan rusak berat, sedangkan untuk parameter pengelolaan tanah pucuk, kedalaman galian, kondisi jalan dan aksesibilitas mempunyai harkat 1 dengan kriteria baik.

Kata Kunci : Potensi kerusakan lingkungan fisik, penambangan breksi batu apung, 


\section{PENDAhuluan}

Sumber daya alam merupakan salah satu modal dasar dalam pembangunan nasional. Oleh karena itu, harus dimanfaatkan sebesar-besarnya untuk kepentingan rakyat dengan memperhatikan kelestarian lingkungan hidup sekitarnya. Sumber daya alam di Indonesia cukup banyak dan melimpah sehingga terkadang sebagian dieksploitasi secara besar-besaran untuk kebutuhan pembangunan. Salah satu kegiatan yang dilakukan dalam memanfaatkan sumber daya alam untuk kebutuhan pembangunan tersebut adalah penambangan breksi batuapung. Kebutuhan akan breksi batuapung ini akan semakin meningkat seiring dengan peningkatan laju pembangunan fisik di berbagai daerah terutama di Kabupaten Bantul dan sekitarnya. Meskipun kegiatan penambangan tersebut sangat menguntungkan dari segi ekonomi, akan tetapi juga harus diimbangi dengan peningkatan kualitas lingkungan hidup yang lain. Dengan demikian, tidak heran jika kegiatan penambangan bahan galian breksi batuapung yang dilakukan secara terus-menerus tanpa adanya wawasan lingkungan akan mengakibatkan menurunnya kualitas lingkungan. Dalam UU No. 32 Tahun 2009 tentang Perlindungan dan Pengelolaan Lingkungan Hidup pasal 1 butir 2 menyatakan bahwa perlindungan dan pengelolaan lingkungan hidup adalah upaya sistematis dan terpadu yang dilakukan untuk melestarikan fungsi lingkungan hidup dan mencegah terjadinya pencemaran dan/atau kerusakan lingkungan hidup yang meliputi perencanaan, pemanfaatan, pengendalian, pemeliharaan, pengawasan, dan penegakan hukum.

Sejalan dengan peningkatan laju pertumbuhan fisik berupa kontruksi, maka usaha pertambangan breksi batuapung akan meningkat pula dilihat dari volume kegiatan penambangan, pemasaran, dan pemenuhan permintaan konsumen terhadap bahan baku industri tersebut. Kegiatan penambangan ini pada dasarnya sangat penting bagi perekonomian daerah sekaligus sebagai pengentasan kemiskinan bagi desa tertinggal sekaligus peningkatan kesempatan kerja. Penambangan breksi batuapung yang dilakukan secara terus-menerus di Desa Segoroyoso memungkinkan terjadinya kerusakan lingkungan fisik di daerah penambangan. Dengan melihat kondisi tersebut serta masih berjalannya kegiatan penambangan breksi batuapung di Desa Segoroyoso, maka perlu dilakukan kajian terhadap kondisi lingkungan fisik untuk mengetahui seberapa besar tingkat kerusakan akibat penambangan breksi batuapung.

\section{Perumusan Masalah}

1. Pengaruh apa saja yang terjadi akibat adanya kegiatan penambangan breksi batuapung terhadap kerusakan lingkungan fisik?

2. Seberapa besar tingkat potensi kerusakan lingkungan fisik akibat penambangan breksi batuapung?

\section{Tujuan penelitian}

Berbeda dengan maksud penelitian yang dikemukakan di atas, penelitian ini memiliki beberapa tujuan sebagai berikut.

1. Mengetahui pengaruh dari penambangan breksi batuapung terhadap kerusakan lingkungan fisik di Desa Segoroyoso, Kecamatan Pleret, Kabupaten Bantul.

2. Menentukan tingkat potensi kerusakan lingkungan fisik berupa kondisi bentuk lahan dan kondisi jalan akibat penambangan breksi batuapung di Desa Segoroyoso, Kecamatan Pleret, Kabupaten Bantul.

\section{Tinjaan Pustaka}

Untuk menjamin terselenggaranya kehidupan dan pembangunan dan berkelanjutan dan terpeliharanya fungsi pelestarian lingkungan, maka pengaturan pengelolaan lingkungan hidup yang memberikan arahan bagi badan hukum dan perseorangan dalam merencanakan dan melaksanakan program pembangunan telah ditetapkan oleh undang-undang No. 32 Tahun 2009 tentang Perlindungan dan Pengelolaan Lingkungan Hidup pasal 1 butir 3 , yang menjelaskan bahwa pembangunan berkelanjutan adalah upaya sadar dan terencana yang memadukan aspek 
lingkungan hidup, sosial, dan ekonomi ke dalam strategi pembangunan untuk menjamin keutuhan lingkungan hidup serta keselamatan, kemampuan, kesejahteraan, dan mutu hidup generasi masa kini dan generasi masa depan.

\section{METODE PENELITIAN \\ Pengertian Kajian}

Kajian adalah hasil dari mengkaji. Sedangkan mengkaji ialah memeriksa, menyelidiki, memikirkan, mempertimbangan, menguji, menelaah baik buruk suatu perkara/ permasalahan (Kamus Besar Bahasa Indonesia, 2000). Keterkaitan dengan penelitian yang akan dilakukan adalah kajian kerusakan lahan akibat penambangan breksi batuapung terhadap lingkungan fisik yang mengacu kepada Keputusan Gubernur Propinsi Daerah Istimewa Yogyakarta Nomor 63 Tahun 2003 tentang Kriteria Baku Kerusakan Lingkungan Bagi Usaha dan/ atau Kegiatan Penambangan Bahan Galian Golongan C di wilayah Provinsi Daerah Istimewa Yogyakarta.

\section{Pengertian Potensi}

Potensi adalah kemampuan yang dapat dikembangkan, kesanggupan untuk berbuat atau melakukan sesuatu, daya, sesuatu yang dipandang dapat menghasilkan (Kamus Lengkap Bahasa Indonesia). Keterkaitan dengan penelitian yang akan dilakukan adalah bahwa adanya potensi kerusakan lahan akibat penambangan breksi batuapung di Desa Segoroyoso, Kecamatan Pleret, Kabupaten Bantul.

\section{Pengertian Lahan dan Kerusakan Lahan}

Berdasarkan defenisi FAO, lahan adalah suatu wilayah daratan yang ciricirinya merangkum semua tanda pengenal (attribute) biosfer, atmosfer, tanah, geologi, timbunan, hidrologi, populasi tumbuhan dan hewan, serta hasil kegiatan manusia masa lalu dan masa kini yang bersifat mantap dan bersifat mendaur sejauh hal-hal tersebut bersifat mendaur atas penggunaan lahan pada masa kini dan masa mendatang. Sedangkan menurut Fandeli C. 1992. lahan merupakan suatu wilayah daratan bumi yang ciri-cirinya mencangkup semua tanda pengenal (attributes) atmosfer, tanah, geologi, timbulan (relief), hidrologi, dan populasi hewan dan tumbuhan, baik yang bersifat mantap maupun yang bersifat mendaur, serta hasil kegiatan manusia masa lalu dan masa kini.

Selain itu, lahan adalah hamparan di muka bumi yang merupakan perpaduan sejumlah sumber daya alam dan binaan. Sumber daya binaan menjadi komponen lahan apabila kehadirannya berpengaruh penting atas penggunaan lahan pada masa kini dan masa mendatang seperti waduk, hamparan sawah, kawasan industri, jaringan jalan, kota dan sebagainya. Lahan merupakan suatu wilayah yakni suatu satuan ruang berupa suatu lingkungan hunian manusia dan hayati lain, lahan menunjuk kepada keseluruhan keadaan luar tempat suatu organisme berada yang mempengaruhi perwujudan organisme atau objek yang lainnya. Jadi, komponen lahan adalah segala tampakan dan gejala baik yang bersifat tetap (misalnya tanah) maupun yang bersifat mendaur (misalnya musim) yang menentukan nilai guna lahan untuk manusia (Notohadinegoro, 1999).

Kerusakan lahan (land degradation) merujuk pada penurunan kapasitas lahan bagi produksi atau penurunan potensi bagi pengelolaan lingkungan, dengan kata lain ialah penurunan mutu tanah dan penurunan mutu air tanah. Kerusakan lahan dapat terjadi karena peristiwa alam (gempa, gerakan massa tanah, dan perubahan iklim), perbuatan manusia (penggundulan vegetasi penutup yang menimbulkan erosi tanah dan /atau banjir, pencemaran badan air karena limbah industri), atau gabungan peristiwa alam dan perbuatan manusia misalnya kebakaran lahan karena musim kemarau yang di pertegas dengan perlakuan berlebih (over-draining) yang dilakukan (Notohadinegoro, 1999).

\section{Pengertian Breksi Batuapung}

Batuapung atau pumice adalah jenis batuapung yang berwarna terang, mengandung buih yang terbentuk dari gelembung berdinding gelas. Batuan ini terbentuk dari magma asam oleh letusan gunung api yang mengeluarkan materialnya ke udara, kemudian mengalami traspormasi 
secara horizontal dan terakumulasi sebagai batuan piroklastik. Breksi batuapung mengandung jumlah sel yang banyak (berstruktur selular) akibat ekspansi buih gas alam yang terkandung di dalamnya, pada umumnya terdapat sebagai bahan lepas atau frakmen-frakmen dalam breksi gunung api. Breksi batuapung tersusun atas batuapung dengan komposisi yang dominan beserta fragmen-frakmen lain seperti mineral felspar, kuarsa, obsidian, kristobalit, dan tridimit (Kurrat, 1993).

Breksi batuapung termasuk ke dalam batuan sedimen klastik di mana fragmen-fragmen batuannya merupakan hasil rombakan dari batuan sebelumnya, komponen fragmen breksi batuapung menunjukan asal batuan merupakan produk kegiatan volkanisme yang mengalami transportasi air. Hal ini terlihat pada komponen batuan berupa fragmen andesit dan batuapung yang cendrung membundar tanggung hingga menyudut tanggung dengan matrik yang halus. Selain informasi tersebut fragmen batuan memberikan gambaran bahwa sumber volkanisme relatif jauh dari tempat diendapkannya. Secara umum breksi batuapung memiliki warna putih keabuan, masif dan menempati daerah-daerah yang memiliki topografi yang tinggi pada gawirgawir yang cukup terjal, batu breksi batuapung di daerah Bantul merupakan bagian dari formasi semilir bagian atas yang tersusun oleh perselingan batupasif tufan, batupasir tufan kerikilan, batulanau tufan dan breksi batuapaung.(Martini, 1999).

\section{Tahap-Tahap dalam Aktivitas Penambangan}

Tahap-tahap dalam aktivitas penambangan modern ada empat macam, antara lain sebagai berikut (Hartman, 1987 dalam Latupono, 2001).

1.Prospecting, bertujuan untuk mencari bahan tambang yang mempunyai nilai jual (mineral logam atau non logam).

2.Exploration, bertujuan untuk mendeterminasi keakuratan cadangan bahan tambang. Pada tahap ini dilakukan studi kelayakan.
3.Development, merupakan tahap pembukaan deposit bahan tambang untuk tahap selanjutnya yaitu produksi, pada tahap ini dilakukan: a) penghentian kegiatan jika pada tahap 2 (tahap ekplorasi) tidak layak tambang; b) studi dampak lingkungan, teknologi yang sesuai, serta perijinan; c) konstruksi akses jalan dan system transportasi; d) penentuan lokasi pabrik dan fasilitas konstruksi; e) pembukaan lahan bahan tambang.

4. Eksploitation, merupakan tahap produksi bahan tambang.

\section{Klasifikasi Pertambangan Mineral}

Berdasar Peraturan Pemerintah Nomor 23 Tahun 2010 tentang Pelaksanaan Kegiatan Usaha Pertambangan Mineral dan Batubara pasal 2 butir 2, bahwa komoditas tambang dikelompokan menjadi 5 golongan, yakni:

a. mineral radioaktif meliputi radium, thorium, uranium, monasit, dan bahan galian radioaktif lainnya;

b. mineral logam meliputi litium, berilium, magnesium, kalium, kalsium, emas, tembaga, perak, timbal, seng, timah, nikel, mangaan, platina, bismuth, molibdenum, bauksit, air raksa, wolfram, titanium, barit, vanadium, kromit, antimoni, kobalt, tantalum, cadmium, galium, indium, yitrium, magnetit, besi, galena, alumina, niobium, zirkonium, ilmenit, khrom, erbium, ytterbium, dysprosium, thorium,cesium,lanthanum, niobium, neodymium, hafnium, scandium, aluminium, palladium, rhodium, osmium, ruthenium, iridium, selenium, telluride, stronium, germanium, dan zenotin;

c. mineral bukan logam meliputi intan, korundum, grafit, arsen, pasir kuarsa, fluorspar, kriolit, yodium, brom, klor, belerang, fosfat, halit, asbes, talk, mika, magnesit, yarosit, oker, fluorit, ball clay, fire clay, zeolit, kaolin, feldspar, bentonit, gipsum, dolomit, kalsit, rijang, pirofilit, kuarsit, zirkon, wolastonit, tawas, batu kuarsa, perlit, garam batu, clay, dan batu gamping untuk semen;

d. batuan meliputi, tras, toseki, obsidian, marmer, perlit, tanah diatome, tanah serap 
(fullers earth), slate, granit, granodiorit, andesit, gabro, peridotit, basalt, trakhit, leusit, tanah liat, tanah urug, batuapung, opal, kalsedon, chert, kristal kuarsa, jasper, krisoprase, kayu terkersikan, gamet, giok, agat, diorit, topas, batu gunung quarry besar, kerikil galian dari bukit, kerikil sungai, batu kali, kerikil sungai ayak tanpa pasir, pasir urug, pasir pasang, kerikil berpasir alami (sirtu), bahan timbunan pilihan (tanah), urukan tanah setempat, tanah merah (laterit), batu gamping, onik, pasir laut, dan pasir yang tidak mengandung unsur mineral logam atau unsur mineral bukan logam dalam jumlah yang berarti ditinjau dari segi ekonomi pertambangan; dan

e. batubara meliputi bitumen padat, batuan aspal, batubara, dan gambut.

\section{Pengertian Lingkungan Hidup}

Undang-Undang Nomor 32 Tahun 2009 tentang Perlindungan dan Pengelolaan Lingkungan Hidup pasal 1 butir 1 menyebutkan bahwa lingkungan hidup adalah kesatuan ruang dengan semua benda, daya, keadaan, dan makhluk hidup, termasuk manusia dan perilakunya, yang mempengaruhi alam itu sendiri, kelangsungan perikehidupan, dan kesejahteraan manusia serta makhluk hidup lain.

Lingkungan hidup sebagai tempat hunian dari waktu ke waktu terus berubah tergantung dengan makhluk hidup di dalamnya. Dengan adanya peningkatan kemampuan manusia akan mempengaruhi perubahan pada lingkungan dengan memanfaatkan sumber daya yang ada seiring dengan peningkatan jumlah manusia dan peningkatan kebutuhan hidup. Dengan perubahan lingkungan akan mengakibatkan lingkungan kurang sesuai untuk mendukung kehidupan manusia dan kesejahteraan makhluk hidup terganggu sehingga perlu adanya pengelolaan dan pemanfaatan secara optimal terhadap lingkungan hidup.

Komponen lingkungan terdiri atas abiotik, biotik dan kultur. Di antara ketiga komponen tersebut terjadi interaksi dan menghasilkan hubungan dinamis setiap perubahan yang terjadi pada salah satu komponen lingkungan selanjutnya akan mempengaruhi komponen lingkungan yang lainnya. Hal ini juga berlaku pada pemanfaatan sumber daya alam.

Hardjasoemantri (1999) menyatakan bahwa pengelolaan lingkungan hidup berasaskan pelestarian kemampuan lingkungan yang serasi dan seimbang untuk menunjang pembangunan yang berkesenambungan bagi kesejahteraan manusia. Pelestarian berasal dari kata lestari yang artinya tidak berubah dan mengandung makna terciptanya kemampuan lingkungan yang selaras, serasi dan seimbang antara komponenkomponen lingkungan yang ada. Pembangunan adalah perubahan menjadi taraf yang telah lebih baik. Apabila dalam proses membangun terjadi dampak negatif terhadap lingkungan maka diupayakan untuk mengurangi dampak negatif tersebut sehingga keadaan lingkungan menjadi selaras, serasi, dan seimbang. Hanya dalam lingkungan yang selaras, serasi, dan seimbang kehidupan optimal dapat tercapai.

\section{Metode Penelitian dan Parameter yang Digunakan}

Metode yang digunakan dalam penelitian mengenai kajian kerusakan lingkungan fifsik akibat penambangan breksi batuapung di Desa Segoroyo, Kecamatan Pleret, kabupaten Bantul yaitu dengan metode survey, pemetaan, dan analisis.

Metode survey yaitu observasi lapangan yang dilakukan untukmengumpulkan datadata yang dibutuhkan mengenai faktor-faktor pendukung dalam penelitian (Arikunto, 2010). Pengertian Pemetaan adalah kegiatan memindahkan unsur-unsur karakteristik lingkungan di lapangan ke dalam peta dasar dalam bentuk titik, garis, dan area (Setyaningsih, 2006). Hasil observasi lapangan dilakukan untuk mengetahui informasi kondisi rona lingkungan hidup dan untuk menentukan areal yang akan dipetakan. Sedangkan pemetaan dilakukan menggunakan alat GPS (Global Position System) dengan akurasi antara dengan 3-5 meter stabil atau seragam, pembuatan peta dilakukan di studio dengan menggunakan 
program Arc View yang dilengkapi dengan 3D Analyst, Image Analyst, selain itu tambahan ekstensi seperti Geo Processing, Xtools, Edit Tools dan Register and Transform.

Analisis kerusakan lingkungan fisik yaitu dengan menggunakan metode pengharkatan (scoring) yang mengacu pada Kep. Gub. Prop. DIY No. 63 Tahun 2003 tentang Kriteria Baku Kerusakan Lingkungan Bagi Usaha dan/ atau Kegiatan Penambangan Bahan Galian Golongan C. Parameter yang digunakan untuk menentukan tingkat potensi kerusakan lingkungan fisik akibat penambangan breksi batuapung dapat dilihat pada Tabel 1 .

\section{Analisis Tingkat Kerusakan Lingkungan Fisik}

Penilaian tingkat kerusakan lingkungan fisik akibat penambangan breksi batuapung yang dilakukan di Desa Segoroyoso, Kecamatan Pleret, Kabupaten Bantul mengacu pada Keputusan Gubernur Daerah Istimewa Yogyakarta Nomor 63 Tahun 2003 tentang Kriteria Baku Kerusakan Lingkungan Bagi Usaha dan/ atau Kegiatan Penambangan Bahan Galian Golongan C di Wilayah Propinsi Daerah Istimewa Yogyakarta. Kep. Gub. DIY No. 63 Th. 2003 tersebut digunakan sebagai acuan penelitian karena Pemerintah daerah Bantul belum mempunyai Peraturan Daerah (PERDA) tentang Kriteria Baku Kerusakan Lingkungan Bagi Usaha dan/atau Kegiatan Penambangan, kemudian lokasi penelitian juga berada di daerah Yogyakarta.
Tabel 1 Parameter Potensi Kerusakan Lingkungan Fisik Akibat Penambangan breksi

Batu apung

\begin{tabular}{|c|c|c|}
\hline No & Komponen & $\begin{array}{c}\text { Parameter Yang } \\
\text { Digunakan }\end{array}$ \\
\hline 1 & $\begin{array}{l}\text { Kondisi } \\
\text { Lingkungan } \\
\text { Fisik }\end{array}$ & $\begin{array}{ll}\text { a. } & \text { Batas kedalaman } \\
\text { lubang galian } \\
\text { b. Penyelamatan tanah } \\
\text { pucuk. } \\
\text { c. Relief dasar galian. } \\
\text { d. Batas kemiringan } \\
\text { tebing galian } \\
\text { e. Tinggi dinding galian } \\
\text { f. Upaya reklamasi } \\
\text { g. } \\
\text { h. Kondisi jalan } \\
\text { i. } \\
\text { j. Aksesibilitas }\end{array}$ \\
\hline
\end{tabular}

Sumber:Kep. Gubernur DIY No. 63 Tahun 2003

Dari analisis pengharkatan dengan pemberian skor pada tiap parameter kerusakan lingkungan fisik berdasarkan kriteria-kriteria yang telah disebutkan sebelumnya, kisaran tingkat kerusakan lingkungan fisik dapat diihat pada tabel 2.

Kondisi potensi kerusakan lingkungan fisik dalam penelitian ini digunakan analisis pemberian harkat/skor terhadap parameter penentu kerusakan yang diamati dan diukur di lapangan.

Tabel 2 Nilai untuk Setiap Parameter Kerusakan Lingkungan Fisik

\begin{tabular}{|c|c|c|c|c|c|}
\hline No & Komponen & \multirow[b]{2}{*}{ Parameter } & \multicolumn{3}{|c|}{ Nilai skor } \\
\hline \multirow{9}{*}{1} & \multirow{9}{*}{$\begin{array}{c}\text { Kondisi } \\
\text { Lingkungan Fisik }\end{array}$} & & Baik & $\begin{array}{l}\text { Rusak } \\
\text { ringan }\end{array}$ & $\begin{array}{c}\text { Rusak } \\
\text { berat }\end{array}$ \\
\hline & & Batas kedalaman lubang galian & 1 & 2 & 3 \\
\hline & & Penyelamatan tanah pucuk & 1 & 2 & 3 \\
\hline & & Relief dasar galian & 1 & 2 & 3 \\
\hline & & Kemiringan dinding galian & 1 & 2 & 3 \\
\hline & & Tinggi dinding galian & 1 & 2 & 3 \\
\hline & & Upaya reklamasi & 1 & 2 & 3 \\
\hline & & Kondisi jalan & 1 & 2 & 3 \\
\hline & & Aksesibilitas & 1 & 2 & 3 \\
\hline
\end{tabular}

Sumber : Survei dan pengukuran lapangan 
Evaluasi Parameter Potensi Lingkungan Fisik

Berdasarkan hasil pengukuran dan survey lapangan dijumpai satu lokasi penambangan breksi batuapung di Dusun Jongkrang, Kelurahan Segoroyoso, yang terdiri dari blok-1, blok-2, dan blok-3. Letak Posisi dan koordinat pada lokasi penelitian dapat di lihat pada tabel.

Tabel 3 Letak posisi dan koordinat lokasi penambngan breksi batuapung di Desa

Segoroyoso

\begin{tabular}{|c|c|}
\hline No & Lokasi \\
\hline 1 & Blok-1 (Dusun Jongkrang) \\
\hline 2 & Blok-2 (Dusun Jongkrang) \\
\hline 3 & Blok-3 (Dusun Jongkrang) \\
\hline
\end{tabular}

Selanjutnya, tiga lokasi penambangan (Blok-1, Blok-2, Blok-3) tersebut dijadikan sampel lokasi penambangan breksi batuapung yang diteliti karakteristik kondisi fisiknya. Gambar 5.1 memperlihatkan peta lokasi penelitian penambangan breksi batuapung di Desa Segoroyoso, Kecamatan Pleret, Kabupaten Bantul. Hasil pengamatan dan pengukuran di lapangan terhadap parameter atau variabel penentu potensi kerusakan lingkungan fisik dari 3 blok di Dusun Jongkrang, Desa Segoroyoso secara ringkas diuraikan sebagai berikut.

\section{Lokasi Penambangan 1 (Blok-1)}

Lokasi penambangan blok1terletak di Dusun Jongkrang, Desa Segoroyoso dengan posisi koordinat $49 \mathrm{M}$ 0434566 dan UTM 9127475. Status kepemilikan lahan adalah milik Kraton Yogyakarta. Kegiatan penambangan tidak memilika surat ijin penambangan daerah (SIPD). Sistem penambangan adalah tambang terbuka yang menggunakan alat tradisional. Hasil perhitungan dan pengamatan setiap variabel yang diamati untuk menentukan potensi kerusakan lahan akibat penambangan breksi batuapung adalah sebagai berikut:

1. Pengelolaan tanah pucuk.
Pada wilayah penelitian ketebalan tanah tanah pucuk berkisar $50 \mathrm{~cm}-1 \mathrm{~m}$, jenis tanahnya berupa tanah lithosol dengan vegetasi berupa jagung, pisang, ubi kayu. Tolok ukur pada kriteria potensi kerusakan lingkungan fisik akibat penambngan breksi batuapung untuk pariabel pengelolaan tanah pucuk

Berdasarkan pengamatan pada blok1 tidak adanya timbunan tanah hasil dari pengupasan tanah pucuk, karena pada waktu pembukaan lahan baru tanah pucuk diselamatkan dan akan digunakan kembali untuk menanam sayuran. Dengan demikian maka kreterianya baik (harkat 1). Gambar berikut menunjukan tanah pucuk yang digunakan kembali.

2. Upaya Reklamasi

Reklamasi adalah kegiatan yang bertujuan memperbaiki atau menata kegunaan lahan yang terganggu sebagai akibat penambangan, agar dapat berfungsi dan berdaya guna sesuai peruntukannya. Waktu reklamasi sebaiknya dilakukan bersamaan dengan kegiatan penambangan, hal ini dilakukan agar keseimbangan lahan yang ditambang dengan pelaksanaan reklamasi dan tidak harus menunggu waktu kegiatan penambangan berakhir. Hasil pengamatan di lokasi penambangan pada blok-1, kegiatan reklamasi tidak dilaksanakan secara bersamaan.

Berdasarkan pengamatan dan wawancara, pada lokasi penambangan blok-1 tidak ada yang melaksanakan kegiatan reklamasi baik saat bersamaan dengan kegiatan penambangan, maupun perencanaan kegitan reklamasi setelah kegitan penambangan berakhir. Dengan demikian, maka kriterianya rusak ( harkat 3)

3. Tinggi dinding galian

Dinding galian adalah pinggiran lubang secara menyeluruh dari permukaan sampai dasar lubang, untuk menjaga stabilitas dinding galian, kemiringan dinding galian secara umum dibatasi maksimum $50 \%$ dan harus dibuat berteras-teras. Setiap teras terdiri dari tebing teras dan dasar teras sebagai parameter yang diamati. Hasil 
pengamatan dan pengkuran di blok-1 yang terbagi kedalam 2 zona pengkuran tidak ditemukan dinding galian yang berbentuk teras-teras.

Hasi pengukuran tinggi dinding galian pada blok-1 dengan pengukuran di 2 zona penambangan. Dari 10 titik pengukuran pada zona 1 dengan rata-rata 11,77 $\mathrm{m}$ dan zona 2 dengan rata-rata 9,6 $\mathrm{m}$. Maka tinggi dinding galian pada blok-1 (zona 1 dan zona 2) termasuk kedalam kriteria rusak (harkat 3). Gambar 5.3 menunjukan tinggi dinding galian pada blok-1.

4. Kemiringan dinding galian.

Kemiringan lahan merupakan salah satu faktor yang menentukan daya dukung lahan bagi suatu peruntukan. Aktivitas penambangan dengan kemiringan lereng di atas $50 \%$ sangat berisiko terhadap longsor dan dapat mengancam keselamatan para pekerja tambang.

Hasi pengukuran kemiringan dinding galian pada blok-1 dengan 2 zona. Dari 10 titik pengkuran pada zona 1 dengan persentasi 76,6\%-100\% dan zona 2 dengan persentasi 66,6\%-100\%. Maka kemiringan dinding galian pada blok-1 termasuk kedalam kriteria rusak (harkat 3)

\section{Relief dasar galian}

Permukaan dasar galian umumnya tidak pernah rata, karena terdapat tumpukan atau onggokan batuan hasil penambangan. Perbedaan relief dasar galian adalah perbedaan ketinggian permukaan onggokan/tumpukan tersebut dengan permukaan dasar galian sekitarnya. Tolok ukur pada kriteria potensi kerusakan lingkungan fisik akibat penambngan breksi batuapung untuk variabel relief dasar galian.

Hasil pengukuran di lapangan dengan 10 titik dan 2 zona dapat dilihat pada tabel 5.4. Bahwa relief dasar galian dan tumpukan batuan sisa galian pada lokasi penambangan blok-1 zona 1 mempunyai tolok ukur rusak sedang (40\%) dan rusak berat $(60 \%)$. Sedangkan pada zona 2 mempunyai tolok ukur rusak sedang $(60 \%)$ dan rusak berat $(40 \%)$

\section{Batas kedalaman galian}

Kedalaman lubang galian adalah jarak vertikal dari permukaan lahan hingga ke dasar lubang galian. Permukaan di sini adalah permukaan awal pada tepi lubang atau garis lurus yang menghubungkan tepi galian sebelum ada galian, sedangkan dasar galian adalah adalah lubang galian yang terdalam. Penentuan batas kedalaman galian yang ditoleril untuk setiap peruntukan lahan ditentukan oleh muka air tanah. Muka air tanah adalah batas lapisan tanah yang jenuh air dengan lapisan tanah yang belum jenuh air. Tolok ukur pada kriteria potensi kerusakan lingkungan fisik untuk penambangan breksi batuapung untuk variabel batas kedalaman galian dapat dilihat pada berrikut dan. Gambar di bawah iniPengukuran kedalaman muka air tanah dan kedalaman galian.

Hasil pengukuran di lapangan dengan 10 titik dengan 2 zona. Bahwa kedalaman galian pada lokasi penambangan blok-1 zona 1 mempunyai tolok ukur baik (100\%) Sedangkan pada zona 2 termasuk kedalam tolok ukur baik (100\%).

7. Kondisi jalan

Dari hasil pengamatan dilapangan pada blok-1, kondisi jalan menuju lokasi penambangan berupa jalan batu bukan jalan aspal yang kondisinya tidak berlubang dan tidak bergelombang. Tolok ukur pada kreteria potensi kerusakan lingkungan fisik penambangan breksi batuapung untuk variabel kondisi jalan dapat dilihat pada tabel 3.9. Hasil pengmatan lapangan kriteria kondisi jalan pada blok-1 adalah baik (harkat 1). Gambar 5.7 poto kodisi jalan menuju penambangan pada blok-1.

8. Aksesibilitas

Jarak lokasi tambang dengan jalan yang ada cukup dekat berkisar 400 meter. Sedangkan jarak dari pusat desa sekitar 1 $\mathrm{km}$ dengan kondisi jalan yang cukup baik. Tolok ukur pada kreteria potensi kerusakan lingkungan fisik penambangan breksi batuapung untuk variabel 
Kajian Potensi Kerusakan Lingkungan Fisik Akibat Penambangan Breksi Batu Apung (Agus Chandra)

aksesibilitas dapat dilihat pada gambar 3.10. Gambar 5.8 menunjukkan akses menuju penambangan. Hasil pengamatan lapangan aksesibilitas daerah penelitian pada blok-1 kriterianya adalah baik (harkat 1) Gambar berikut akses jalan menuju penambangan.

\section{Analisis Potensi Kerusakan Lingkungan Fisik}

Tingkat potensi kerusakan lingkungan fisik ditentukan oleh perhitungan dan penilaan terhadap parameter penentu seperti yang telah diuraikan pada bab III yakni tabel berikut.

\begin{tabular}{|c|c|c|c|}
\hline \multirow{3}{*}{ No } & \multirow{3}{*}{ Parameter } & \multirow{2}{*}{\multicolumn{2}{|c|}{$\begin{array}{c}\text { Hasil perhitungan } \\
\text { Blok } 1\end{array}$}} \\
\hline & & & \\
\hline & & Zona I & Zona II \\
\hline 1 & $\begin{array}{l}\text { Penyelamatan } \\
\text { Tanah Pucuk }\end{array}$ & \multicolumn{2}{|c|}{ - } \\
\hline 2 & Upaya Reklamasi & \multicolumn{2}{|r|}{-} \\
\hline T & $\begin{array}{l}\text { Tinggi Dinding } \\
\text { Galian }\end{array}$ & $9 m-15 m$ & $\begin{array}{c}7,5 \mathrm{~m}- \\
12 \mathrm{~m}\end{array}$ \\
\hline $\begin{array}{l}\mathrm{K} \\
\mathrm{L}\end{array}$ & $\begin{array}{l}\text { Kemiringan } \\
\text { Dinding Galian }\end{array}$ & $\begin{array}{l}76,6 \%- \\
100 \%\end{array}$ & $\begin{array}{l}66,6 \%- \\
100 \%\end{array}$ \\
\hline $\mathrm{F}$ & $\begin{array}{l}\text { Relief Dasar } \\
\text { Galian }\end{array}$ & $\begin{array}{l}0,9 m- \\
1,3 m\end{array}$ & $\begin{array}{l}0,6 \mathrm{~m}- \\
1,2 \mathrm{~m}\end{array}$ \\
\hline E & $\begin{array}{l}\text { Batas Kedalaman } \\
\text { Galian }\end{array}$ & $1 \mathrm{~m}-2,1 \mathrm{~m}$ & $\begin{array}{l}1,1 \mathrm{~m}- \\
1,8 \mathrm{~m}\end{array}$ \\
\hline 7 & Kondisi Jalan & \multicolumn{2}{|c|}{ - } \\
\hline 8 & Aksesibilitas & \multicolumn{2}{|r|}{-} \\
\hline \multicolumn{4}{|c|}{ Hasil perhitungan } \\
\hline \multicolumn{2}{|r|}{ Blok 2} & \multicolumn{2}{|c|}{ Blok 3} \\
\hline Zona I & Zona II & Zona I & Zona II \\
\hline \multicolumn{2}{|r|}{-} & \multicolumn{2}{|c|}{-} \\
\hline \multicolumn{2}{|r|}{ - } & \multicolumn{2}{|c|}{-} \\
\hline $3,7 \mathrm{~m}-8,1 \mathrm{~m}$ & $4,2 \mathrm{~m}-6,4 \mathrm{~m}$ & 3,8m-7,2m & 4,9m-6,7m \\
\hline $\begin{array}{l}51,1 \%- \\
67,7 \%\end{array}$ & $\begin{array}{l}\mathbf{5 5 , 5 \% -} \\
\mathbf{7 5 , 5 \%} \\
\end{array}$ & $\begin{array}{l}44,4 \%- \\
63,3 \% \\
\end{array}$ & $\begin{array}{l}46,6 \%- \\
62,2 \% \\
\end{array}$ \\
\hline $0,7 \mathrm{~m}-1,1 \mathrm{~m}$ & $0,6 \mathrm{~m}-1,2 \mathrm{~m}$ & $0,5 \mathrm{~m}-1,3 \mathrm{~m}$ & $0,7 \mathrm{~m}-1,2 \mathrm{~m}$ \\
\hline $0,9 m-1,5 m$ & $0,8 m-2,2 m$ & $0,9 \mathrm{~m}-2,1 \mathrm{~m}$ & $0,9 \mathrm{~m}-1,7 \mathrm{~m}$ \\
\hline \multicolumn{2}{|r|}{-} & \multicolumn{2}{|c|}{ - } \\
\hline \multicolumn{2}{|r|}{-} & \multicolumn{2}{|c|}{ - } \\
\hline
\end{tabular}

Berdasarkan hasil perhitungan potensi kerusakan lingkungan fisik pada tabel di atas, maka dapat diketahui pada tiap lokasi penambangan blok-1 mempunyai potensi kerusakan lingkungan fisik sebagai berikut

Tabel 4 klasifikasi potensi kerusakan lingkungan fisik pada blok-1

\begin{tabular}{|c|c|c|c|c|}
\hline No & Parameter & Blok 1 & keterangan & Harkat \\
\hline 1 & $\begin{array}{l}\text { Penyelamatan } \\
\text { tanah pucuk }\end{array}$ & Zona I & Baik & 1 \\
\hline 2 & $\begin{array}{l}\text { Upaya } \\
\text { Reklamasi }\end{array}$ & Zona I & Rusak berat & 3 \\
\hline 3 & $\begin{array}{l}\text { Tinggi } \\
\text { Dinding } \\
\text { Galian } \\
\end{array}$ & $\begin{array}{l}\text { Zona I } \\
\text { Zona } \\
\text { II } \\
\end{array}$ & $\begin{array}{l}\text { Rusak berat } \\
\text { Rusak berat }\end{array}$ & $\begin{array}{l}3 \\
3\end{array}$ \\
\hline 4 & $\begin{array}{l}\text { Kemiringan } \\
\text { Dinding } \\
\text { Galian }\end{array}$ & $\begin{array}{l}\text { Zona I } \\
\text { Zona } \\
\text { II }\end{array}$ & $\begin{array}{l}\text { Rusak berat } \\
\text { Rusak berat }\end{array}$ & $\begin{array}{l}3 \\
3\end{array}$ \\
\hline 5 & $\begin{array}{l}\text { Relief Dasar } \\
\text { Galian }\end{array}$ & $\begin{array}{l}\text { Zona I } \\
\text { Zona } \\
\text { II }\end{array}$ & $\begin{array}{c}\text { Rusak sedang } \\
\text { dan rusak berat } \\
\text { Rusak Sedang } \\
\text { dan Rusak } \\
\text { barat }\end{array}$ & $\begin{array}{l}2 \text { dan } 3 \\
2 \text { dan } 3\end{array}$ \\
\hline 6 & $\begin{array}{l}\text { Batas } \\
\text { Kedalaman } \\
\text { Galian }\end{array}$ & $\begin{array}{l}\text { Zoan I } \\
\text { Zona } \\
\text { II }\end{array}$ & $\begin{array}{l}\text { Baik } \\
\text { Baik }\end{array}$ & $\begin{array}{l}1 \\
1\end{array}$ \\
\hline 7 & Kondisi Jalan & Zona I & Baik & 1 \\
\hline 8 & Aksesibilitas & Zona I & Baik & 1 \\
\hline
\end{tabular}

Berdasarkan hasil perhitungan potensi kerusakan lingkungan fisik pada tabel 5.14 di atas, maka dapat diketahui pada tiap lokasi penambangan blok-2 mempunyai potensi kerusakan lingkungan fisik sebagai berikut.

Tabel 5 Klasifikasi potensi kerusakan lingkungan fisik pada blok-2

\begin{tabular}{|c|c|c|c|c|}
\hline No & Parameter & $\begin{array}{c}\text { Blok } \\
2\end{array}$ & keterangan & Harkat \\
\hline 1 & $\begin{array}{l}\text { Penyelamatan } \\
\text { tanah pucuk }\end{array}$ & $\begin{array}{l}\text { Zona } \\
\text { I }\end{array}$ & Baik & 1 \\
\hline 2 & $\begin{array}{l}\text { Upaya } \\
\text { Reklamasi }\end{array}$ & $\begin{array}{l}\text { Zona } \\
\text { I }\end{array}$ & Rusak berat & 3 \\
\hline \multirow{2}{*}{3} & \multirow{2}{*}{$\begin{array}{l}\text { Tinggi } \\
\text { Dinding } \\
\text { Galian }\end{array}$} & $\begin{array}{l}\text { Zona } \\
\text { I }\end{array}$ & Rusak berat & 3 \\
\hline & & $\begin{array}{l}\text { Zona } \\
\text { II }\end{array}$ & Rusak berat & 3 \\
\hline \multirow{2}{*}{4} & \multirow{2}{*}{$\begin{array}{l}\text { Kemiringan } \\
\text { Dinding } \\
\text { Galian }\end{array}$} & $\begin{array}{l}\text { Zona } \\
\text { I }\end{array}$ & Rusak berat & 3 \\
\hline & & $\begin{array}{l}\text { Zona } \\
\text { II }\end{array}$ & Rusak berat & 3 \\
\hline \multirow{2}{*}{5} & \multirow{2}{*}{$\begin{array}{l}\text { Relief Dasar } \\
\text { Galian }\end{array}$} & $\begin{array}{l}\text { Zona } \\
\text { I }\end{array}$ & $\begin{array}{c}\text { Rusak } \\
\text { sedang dan } \\
\text { rusak berat }\end{array}$ & 2 dan 3 \\
\hline & & $\begin{array}{l}\text { Zona } \\
\text { II }\end{array}$ & $\begin{array}{c}\text { Rusak } \\
\text { sedang dan } \\
\text { rusak berat }\end{array}$ & 2 dan 3 \\
\hline \multirow[b]{2}{*}{6} & \multirow{2}{*}{$\begin{array}{l}\text { Batas } \\
\text { Kedalaman } \\
\text { Galian }\end{array}$} & $\begin{array}{l}\text { Zoan } \\
\text { I }\end{array}$ & Baik & 1 \\
\hline & & $\begin{array}{l}\text { Zona } \\
\text { II }\end{array}$ & Baik & 1 \\
\hline 7 & Kondisi Jalan & $\begin{array}{l}\text { Zona } \\
\text { I }\end{array}$ & Baik & 1 \\
\hline 8 & Aksesibilitas & $\begin{array}{l}\text { Zona } \\
\text { I }\end{array}$ & Baik & 1 \\
\hline
\end{tabular}


Berdasarkan hasil perhitungan potensi kerusakan lingkungan fisik pada tabel di atas, maka dapat diketahui pada tiap lokasi penambangan blok-3 mempunyai potensi kerusakan lingkungan fisik sebagai berikut.

Tabel 6 Klasifikasi potensi kerusakan lingkungan fisik pada blok-3

\begin{tabular}{|c|c|c|c|c|}
\hline No & Parameter & Blok 3 & keterangan & $\begin{array}{l}\text { Har } \\
\text { kat }\end{array}$ \\
\hline 1 & $\begin{array}{l}\text { Penyelamat } \\
\text { an tanah } \\
\text { pucuk }\end{array}$ & Zona I & Baik & 1 \\
\hline 2 & $\begin{array}{l}\text { Upaya } \\
\text { Reklamasi }\end{array}$ & Zona I & Rusak sedang & 2 \\
\hline 9 & $\begin{array}{l}\text { Tinggi } \\
\text { Dinding } \\
\text { Galian }\end{array}$ & $\begin{array}{l}\text { Zona I } \\
\text { Zona II }\end{array}$ & $\begin{array}{l}\text { Rusak berat } \\
\text { Rusak berat }\end{array}$ & $\begin{array}{l}3 \\
3\end{array}$ \\
\hline 10 & $\begin{array}{l}\text { Kemiringan } \\
\text { Dinding } \\
\text { Galian }\end{array}$ & Zona II & $\begin{array}{l}\text { Rusak sedang } \\
\text { dan rusak } \\
\text { berat } \\
\text { Rusak sedang } \\
\text { dan rusak } \\
\text { berat } \\
\end{array}$ & $\begin{array}{c}2 \\
\text { dan } \\
3 \\
2 \\
\text { dan } \\
3 \\
\end{array}$ \\
\hline 11 & $\begin{array}{l}\text { Relief } \\
\text { Dasar } \\
\text { Galian }\end{array}$ & Zona II & $\begin{array}{c}\text { Rusak sedang } \\
\text { dan rusak } \\
\text { berat } \\
\text { Rusak sedang } \\
\text { dan rusak } \\
\text { berat } \\
\end{array}$ & $\begin{array}{c}2 \\
\text { dan } \\
3 \\
2 \\
\text { dan } \\
3 \\
\end{array}$ \\
\hline 12 & $\begin{array}{l}\text { Batas } \\
\text { Kedalaman } \\
\text { Galian } \\
\end{array}$ & $\begin{array}{l}\text { Zoan I } \\
\text { Zona II }\end{array}$ & $\begin{array}{l}\text { Baik } \\
\text { Baik }\end{array}$ & $\begin{array}{l}1 \\
1\end{array}$ \\
\hline 13 & $\begin{array}{l}\text { Kondisi } \\
\text { Jalan }\end{array}$ & Zona I & Baik & 1 \\
\hline 14 & $\begin{array}{l}\text { Aksesibilita } \\
\mathrm{S}\end{array}$ & Zona I & Baik & 1 \\
\hline
\end{tabular}

\section{Pendekatan Pengelolaan}

Dari hasil pengamatan dan pengukuran variabel tingkat potensi kerusakan lingkungan fisik pada lokasi penelitian, bahwa usaha pertambangan yang dilaksanakan di Desa Segoroyoso ini telah menimbulkan kerusakan lingkungan fisik dari blok-I, blok-II dan blok-III dengan tingkat kerusakan berat, sedang dan ringan. Meskipun demikian, perlu dilakukan penanganan dan pengelolaan lingkungan lebih lanjut agar kerusakan lingkungan fisik di daerah penambangan yang terjadi tidak meluas dan segera dapat diatasi seiring dengan perjalanan waktu. Sistem pengelolaan lingkungan adalah tindakan yang terpadu dari berbagai komponen yang bertujuan untuk menangani dampak yang terjadi. Tindakan ini berupa pemanfaatan, penataan, pemeliharaan, pengawasan, pengendalian dan pengembangan lingkungan hidup. Wujud dari usaha pengelolaan tersebut adalah menentukan tindakan yang tepat dan efektif guna tercapai tujuan dalam mewujudkan lingkungan yang bebas dari kerusakan. Dalam penerapannya ada 4 (empat) pendekatan, yaitu pendekatan teknologi, pendekatan ekonomi, pendekatan institusi dan pendekatan sosial.

\section{Pendekatan Teknologi}

Pengelolaan lingkungan dapat ditempuh dengan cara-cara teknologi untuk menangani dampak lingkungan, pencegahan dan penanggulangan dampak negatif serta mengembangkan dampak positifnya, mengurangi dan memperbaiki kerusakan dan pemanfaatan sumberdaya alam secara optimal. Pendekatan teknologi yang tepat untuk menangani potensi kerusakan lingkungan fisik ini berupa teknik penambangan yang baik dan benar dan dilakukannya upaya reklamasi.

\section{a. Teknik Penambangan}

Teknik atau cara penambangan sangat berpengaruh terhadap kualitas lingkungan. Teknik penambangan yang salah akan mengakibatkan rusaknya bentuk lahan di sekitar penambangan. Tingginya dinding galian yang tidak berbuat berjenjang atau berteras akan rawan erosi dan longsor dalam pengerjaannya. Untuk menjaga satabilitas dinding galian, kemiringan lereng dinding galian dibatasi maksimum $50 \%$ dan harus dibuat berjenjang. Sedangkan tinggi tebing jenjang dibatasi maksimum 3 meter sehingga terjaganya batas toleransi bagi keamanan lingkungan sekitar. Sedangkan lebar dasar teras minimum 6 meter untuk mempertahankan kemiringan dinding galian tidak lebih curam dari 50\% ( kepmen Lingkungan Hidup no 43 Tahun 1996).

\section{b. Upaya reklamasi}

Untuk mengurangi dampak negatif dari aktivitas penambangan, reklamasi harus 
dilakukan sejak awal yaitu selama maupun setelah kegiatan penambangan. Reklamasi pada areal bekas penambangan merupakan satu kesatuan kegiatan yang tidak terpisahkan dengan aktivitas penambangan itu sendiri. Oleh karena itu, diperlukan perencanaan yang matang dalam menyusun kegiatan reklamsi.

\section{c. Pendekatan ekonomi}

Dalam rangka menanggulangi dampak besar dan penting dari aspek sosial ekonomi, budaya dan kesehatan masyarakat maka upaya-upaya yang dilakukan adalah sebagai berikut.

a. Memprioritaskan penyerapan tenaga kerja lokal sesuai dengan keahlian dan keterampilan yang dimiliki.

b. Meningkatkan usaha usaha pertanian baik sayuran maupun ubikayu sebagai mata pencarian awal para penambang agar kerusakan lingkungan dari kegitan penambngan dapat dikurangi.

\section{Pendekatan institusi}

Pendekatan institusi yang dapat dilakukan adalah.

a. Kerja sama dengan instansi terkait seperti Kantor Lingkungan Hidup untuk melaksanakan pengelolaan lingkungan.

b. Pengawasan dan pemantauan terhadapa hasil untuk kerja pengelolaan lingkungan oleh instansi berwenang.

c. Pelaporan hasil pengelolaan lingkungan secara berkala kepada pihak yang berkepentingan.

\section{Pendekatan sosial}

Sebagai para pelaku atau pekerja tambang, kondisi sosial dan ekonomi yang relatif rendah menyebabkan timbulnya keterbatasan dalam pemahaman pengembangan usaha di bidang pertambangan yang berwawasan lingkungan. Untuk itu, perlu dilakukan pengarahan dan pembinaan mengenai keselamatan kerja dan teknik pertambangan yang baik dan benar. Dengan demikian, kecelakaan kerja dan kerusakan lingkungan dapat dihindari.

\section{Pengelolaan Lahan Bekas Tambang pada Lokasi Penelitian}

Cara penambangan di Desa Segoroyoso pada umumnya adalah dengan memotong pada sisi bukit. Hal ini akan meninggalkan bekas penambangan berupa jenjang-jenjang yang cukup tinggi dan curam. Keadaan ini akan menimbulkan bahaya erosi dan longsor. Berdasarkan kondisi lahan tersebut, untuk menunjang dan mempermudah upaya reklamasi jangka pendek dan jangka panjang yaitu diperuntukan sebagai lahan pertanian. Maka terlebih dahulu dilakukan penanganan lahan bekas tambang yaitu:

\section{Penataan jenjang}

Penataan jenjang pada lahan bekas penambangan yang ditinggalkan penting dilaksanakan terlebih dahulu. Kemiringan dan panjang jenjang adalah dua unsur yang mempengaruhi terhadap aliran permukaan dan erosi. Selain itu jenjang yang curam dapat membahayakan lingkungan di bawah jika terjadi longsor. Penataan jenjang dimaksudkan untuk mengurangi kesepatan aliran air permukaan, erosi dan sedimentasi yang sangat berperan dalam kesuburan tanah. Untuk mengurangi kerusakan lahan khususnya kesuburan tanah tersebut termasuk unsur hara maka perlu dilakukan pengaturan pembuangan air, penanaman tanaman penutup, mengurangi kemiringan lahan dan sebagainya.

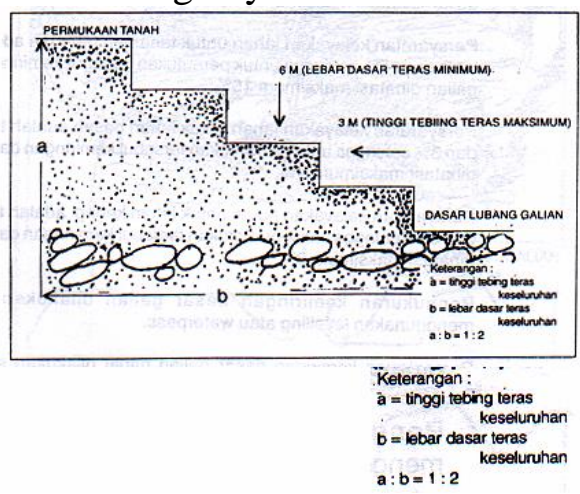

Gambar 1 Sketsa dinding galian yang disyaratkan untuk semua diperuntukan(Kepmen Lingkungan Hidup No.43 Tahun 1996) 
7. Penanganan lapisan tanah pucuk

Cara pengamanan tempat penimbunan lapisan tanah pucuk ada bermacam-macam tergantung dari keadan topografinya. Berikut ini adalah alternatif cara penimbunan tanah pucuk untuk daerah penimbunan.

a. relatif miring(lereng berbukit), harus diberi pengamanan tanggul dibagian bawah dan saluran air dibagian atasnya. (Gambar 6.2)

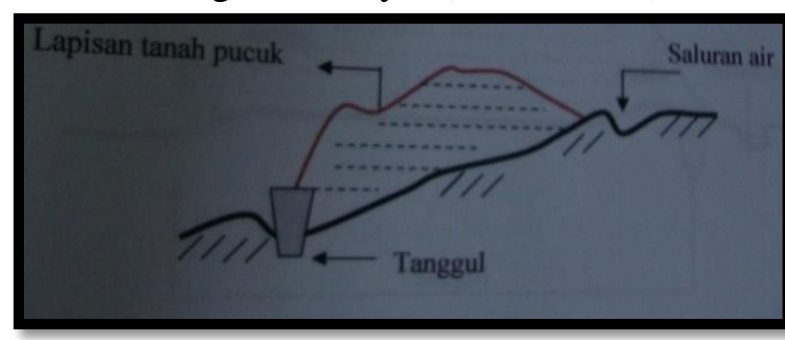

Gambar 2 Cara penimbunan lapisan tanah pucuk (Nugroho,2003)

b. Datar untuk waktu yang tidak lama, maka cukup dengan pemasangan tanggul-tanggul dan saluran air dibagian atas (Gambar 6.3

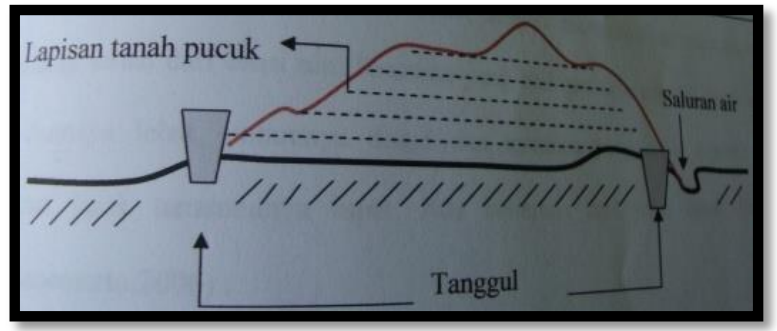

Gambar 3 Cara penimbunan tanah pucuk pada daerah datar(Nugroho,2003)

c. Datar untuk waktu yang relatif lama, cara pengamanannya dengan tanggul dan sebaiknya ditanami rumput-rumputan untuk memcegah erosi (Gambar )

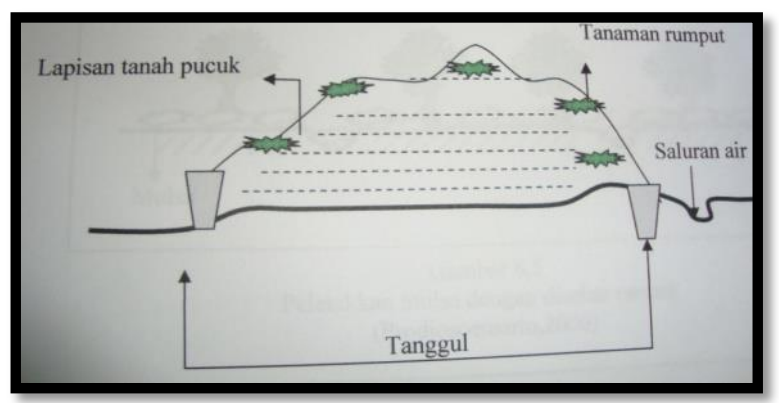

Gambar 4 Cara penimbunan lapisan tanah pucuk pada daerah datar dengan tanaman rumput(Nugroho,2003

\section{KESIMPULAN}

Berdasarkan hasil penelitian mengenai "Kajian potensi kerusakan lingkungan fisik akibat pernambangan breksi batuapung di Desa Segoroyoso, Kecamatan Pleret, Kabupaten Bantul, DIY" dapat disimpulkan sebagai berikut.

1. Bahwa kegiatan penambangan ini telah menimbulkan kerusakan potensi lingkungan fisik meliputi :

a. Tinggi dinding galian pada tiap lokasi penambangan mempunyai ketinggian di atas 4 meter, dengan kriteria rusak berat (harkat 3)

b. Kemiringan galian yang curam sangat membahayakan bagi setiap para pekerja tambang, pada dua lokasi penelitian ( blok-1 dan blok-2) mempunyai kriteria rusak berat. Sedangkan pada Blok 3 mempunyai kriteria rusak sedang sampai dengan rusak berat.

c. Pengelolaan relief dasar galian yang kurang baik membuat kondisi lokasi penambangan tidak rata dan banyak cekungan, pada setiap lokasi penelitian( blok-1, blok 2, dan blok3) mempunyai kriteria rusak sedang sampai dengan rusak berat.

d. Upaya reklamasi yang belum maksimal dilaksanakan, pada lokasi penelitian blok-1 dengan harkat 3 (rusak berat) blok-2 dengan harkat 3 (rusak berat) dan blok-3 dengan harkat 2 (rusak ringan/sedang).

2. Untuk parameter pengelolaan tanah pucuk, kedalaman galian, kondisi jalan, dan aksesibilitas masih dalam ambang batas yang baik, pada lokasi penelitian dari blok-1, blok-2, dan blok-3 mempunyai harkat 1 (dikategorikan baik). 
3. Tingkat potensi kerusakan lingkungan fisik yang sangat dominan terdapat pada tinggi dinding galian, kemiringan dinding galian, relief dasar galian dan upaya reklamasi, hal ini terjadi karena jarak pada lokasi tambang cukup berdekatan, dengan topografi yang relatif sama dan cara penambangan pada tiap lokasi secara tradisional.

\section{Saran}

1) Adanya pengarahan dari pihak yang terkait terhadap para penambang mengenai cara penambangan yang baik dan benar agar mengurangi risiko kecelakan.

2) Keterlibatan tokoh masyarakat desa bekerja sama dengan instansi terkait mengenai aktivitas penambangan agar penambangan yang dilakukan berwawasan lingkungan melalui pendekatan-pendekatan yang ada karena kegiatan ini sulit untuk dihentikan terkait dengan persoalan ekonomi. Kendala-kendala yang dihadapai adalah sulitnya pendekatan dengan para penambang untuk beralih menjadi petani atau buruh bangunan, karena pendapatan dari kegiatan penambangan lebih cepat menguntungkan dari pada sebagai petani yang mendapatkan keuntungan secara musiman. Hal ini dapat diatasi dengan penyuluhan tentang pertanian dan peningkatan produktivitas pertanian.

3) Kegiatan reklamasi sebaiknya dilakukan baik pada setiap kegiatan penambangan berlansung dan pasca penambangan agar tanah pucuk yang ada dapat segera digunakan untuk penanaman kembali serta dapat meminimalisasikan potensi kerusakan lingkungan.

Menurut Alathas, 2005. Ada beberapa cara reklamasi pada permukaan yang sudah datar antara lain :
a. Perataan permukaan tanah, keadaan ini dilakukan apabila tanah yang tersedia cukup banyak

b. Pembuatan tumpukan, dilakukan apabila tanah pucuk yang tersedia hanya sedikit dan hanya terbatas.

c. Membuat lubang (pot), dilakukan apabila jumlah tanah sangat sedikit dan tebatas serta untuk mengurangi biaya pemindahan tanah.

d. Menjadikan sebagai lahan permukiman atau lapangan olahraga, dilakukan apabila jumlah tanah pucuk sangat tipis dan lahan bekas penambangan berupa dataran.

e. Menjadikan sebagai kolam tadah hujan, khusus untuk penggalian yang meninggalkan lahan bekas penambangan dalam bentuk cekungan.

\section{DAFTAR PUSTAKA}

Anonim, 2009, Undang-Undang Republik Indonesia No. 4 Tahun 2009, Tentang Pertambangan Mineral dan Batu Bara, Jakarta.

Anonim, 2009, Undang-Undang Republik Indonesia No. 32 Tahun 2009, Tentang Perlindungan dan pengelolaan Lingkungan Hidup, Jakarta.

Anonim, 2010, Peraturan Pemerintah Republik Indonesia Nomor 23 Tahun $2010 \quad$ Tentang Pelaksanaan Kegiatan Usaha Pertambangan Mineral dan Batubara,Jakarta

Anonim, 2008, Peraturan Menteri Energi dan Sumberdaya Mineral No. 18 Tahun 2008, Tentang Reklamasi dan Penutupan Tambang, Jakarta.

Anonim, 1996, Keputusan Menteri Lingkungan Hidup No. 43 Tahun 1996, Tentang Kriteria Kerusakan Lingkungan Bagi Usaha Dan Kegiatan Penambangan Bahan Galian Golongan CJenis Lepas Di Dataran, Jakarta. 
Anonim, 2003, Keputusan Gubernur Propinsi Daerah Istimewa Yogyakarta No.63 Tahun 2003, Tentang Kriteria Baku Kerusakan Lingkungan Bagi Usaha Dan/Atau Kegiatan Penambangan Bahan Galian Golongan C Di Wilayah Propinsi Daerah Istimewa Yogyakarta. Yogyakarta

Anonim, 1986, Direktorat Geologi dan Sumberdaya Mineral, Buku Petunjuk Usaha Pertambangan Bahan Galian Golongan $C$. Ditjen Pertambangan Umum

Alathas, Said Fadhillah, 2005, Reklamasi dan Perencanaan Pemamfaatan serta Tataguna Lahan Bekas Tambang Dalam Rangka Workshop dan Pelatihan Perencanaan Pengakhiran dan Pasca Tambang, Yogyakarta

Latupono, S, 2005, Kajian Kerusakan Laingkungan Akibat Penambangan Pasir dan Batu di Desa Waeheru Kecamatan Teluk Ambon Baguala Kota Ambon, Tesis Pascasarjana Universitas Gajah Mada, Yogyakarta

Fandeli.C., 1992, Analisis Mengenai Dampak Lingkungan, Prinsip Dasar, Dan Pemaparannya Dalam Pembangunan, Liberty, Yogyakarta

Joni purba, 2005, Pengelolaan Lingkungan

Sosial Kantor Menteri Negara

Lingkungan Hidup, yayasan obor Indonesia, Jakarta

Hardiyatmo.H.C., 1998, Bahan Galian Industri, Gadjah Mada University Press, Yogyakarta

Kusumawardani.D., 2005, Prediksi Laju

Erosi Dengan Menggunakan

Metode USLE Pada sub DAS

Krasak Kabupaten Sleman"

Skripsi. Fakultas Geografi, Universitas Gadja Mada, Yogyakarta
Notohadiprawiro.T., 2006, Lahan Kritis dan Bincangan Pelestarian Lingkungan Hidup, Ilmu Tanah Universitas Gadja Mada , Yogyakarta

Notohadiprawiro.T., 2006, Pengelolaan Lahan dan Lingkungan Pasca Penambangan, Ilmu Tanah Universitas Gadja Mada , Yogyakarta

Arikunto, Suharsimi. 2010, Prosedur Penelitian Suatu Pendekatan Praktik, Rineka Cipta. Jakarta

Soerjani, M., Ahmad, R., dan Munir, R., 1987, Lingkungan Sumberdaya Alam dan Kependudukan Dalam Pembangunan, UIP, Jakarta.

This is an open access article which
means that all content is freely
available without charge to the user or
his/her institution. Jurnal Saintis allows the author(s) to
hold the copyright without restriction. The copyright in the
text of individual articles (including research articles,
opinion articles, and abstracts) is the property of their
respective authors distributed under the terms of the
Creative Commons Attribution-ShareAlike 4.0 International
License(https://creativecommons.org/licenses/by-sa/4.0/)
which permits unrestricted use, distribution, and
reproduction in any medium. Users are allowed to read,
download, copy, distribute, search, or link to full-text
articles in this journal without asking by giving appropriate
credit, provide a link to the license, and indicate if changes
were made.
were made. 